UCRL-ID-119563

\title{
Absorption of Sparingly Soluble Gases by Reactive Media in Self-Aerated Gas-Liquid Contactors: a Scale-up Procedure
}

\author{
Yury Zundelevich
}

January 1995

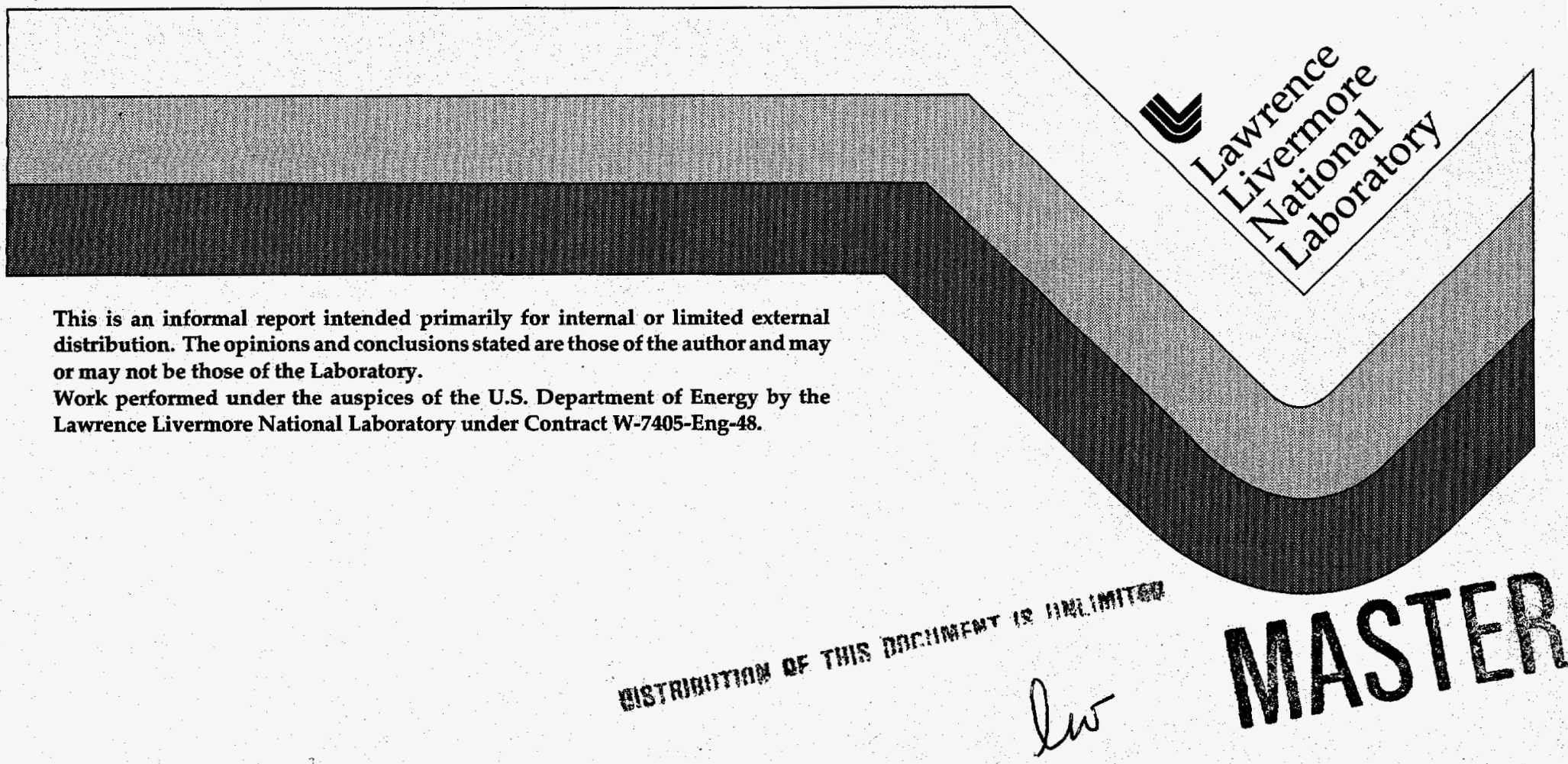

This is an informal report intended primarily for internal or limited external distribution. The opinions and conclusions stated are those of the author and may or may not be those of the Laboratory.

Work performed under the auspices of the U.S. Department of Energy by the Lawrence Livermore National Laboratory under Contract W-7405-Eng-48. 


\section{DISCLAIMER}

This document was prepared as an account of work sponsored by an agency of the United States Government. Neither the United States Government nor the University of California nor any of their employees, makes any warranty, express information, or assumes any legal liability or responsibility for the accuracy, completeness, or usefulness of any rights. Reference herein to any, or process disclosed, or represents that its use would not infringe privately owned manufacturer, or otherwise any specific commercial product, process, or service by trade name, trademark, the United States Government or the Uecessarily constitute or imply its endorsement, recommendation, or favoring by not necessarily state or reflect those of the United California. The views and opinions of authors expressed herein do not necessarily state or reflect those of the United States Government or the University of California, and shall not be
used for advertising or product endorsement purposes.

This report has been reproduced directly from the best available copy.

Available to DOE and DOE contractors from the Office of Scientific and Technical Information P.O. Box 62, Oak Ridge, TN 37831

Prices available from $(615) 576-8401$, FTS 626-8401

Available to the public from the National Technical Information Service

U.S. Department of Commerce 5285 Port Royal Rd.

Springfield, VA 22161

\section{DISCLAIMER}

This report was prepared as an account of work sponsored by an agency of the United States Government. Neither the United States Government nor any agency thereof, nor any of their implied, or assumes any legal liability or responsiemployees, makes any warranty, express or implies, of any information, apparatus, product, or bility for the accuracy, completeness, or usefulness of any ing rivately owned rights. Referprocess disclosed, or represents that its use would not infringe privaly by trade name, trademark,
ence herein to any specific commercial product, process, or service by manufacturer, or otherwise does not necessarily constitute or imply its endorsement, recommendation, or favoring by the United States Government or any agency theref. The of the and opinions of authors expressed herein do not

United States Government or any agency thereof. 


\section{DISCLAIMER}

Portions of this document may be illegible in electronic image products. Images are produced from the best available original document. 


\title{
Absorption of Sparingly Soluble Gases \\ by Reactive Media in Self-Aerated Gas-Liquid Contactors: \\ a Scale-up Procedure
}

\author{
Yury Zundelevich
}

\section{Introduction}

Absorption of sparingly soluble gases, such as $\mathrm{NO}$ or $\mathrm{O}_{2}$, is greatly enhanced and, indeed, made possible if the latter react with the media. Among a dozen of reactive solvents for $\mathrm{NO}_{\mathrm{x}}$ abatement reviewed by Jethani et al. (1990) [1] aqueous acidic urea appears the most economically and environmentally attractive because urea is a cheap reagent and because products of reaction of urea with nitrous acid, formed in the liquid phase via absorption of $\mathrm{NO}$ and $\mathrm{NO}_{2}$, are carbon dioxide and nitrogen, which can be directly released into the atmosphere. That makes urea process unique among other wet scrubbing processes that routinely produce secondary waste. The urea process has been patented by Warshaw (1971) in the USA and by Dyens (1985) in France but its full potential has never been realized, perhaps due to the lack of an efficient gasliquid contactor to overcome low solubility of NO in aqueous solutions.

In conjunction with the electrochemical destruction of organics (MEO) in waste streams, LLNL has recently designed and built a bench scale gas-liquid contactor for nitric acid regeneration with oxygen. The contactor proved very effective in overcoming the problem of low solubility of oxygen converting back to nitric acid approximately $99 \%$ of nitrous acid formed at the cathode (which would otherwise convert to $\mathrm{NO}_{\mathrm{X}}$ ). The history of the contactor goes back to the seventies when it was developed by Zundelevich $(1975,1979)$ [3-4] for oxidative pressure leaching with oxygen in the former Soviet Union. The bench scale contactor consists of a 12" diameter tank with self-inducting impeller/aerator of very high gas capacity. The aerator represents a 3.5" turbine mounted on a vertical shaft inside the draft tube equipped with a stator. During operation the lower half of the turbine induces liquid and the upper half induces gas from the draft tube. Fine gas-liquid dispersion with large mass transfer area is formed within the high shear rate zone of rotor-stator assembly yielding mass transfer rates unattainable in conventional packed absorbers. Once the gas, in the form of bubbles, reaches the surface it is drawn again into the draft tube (and thus given another chance to pass through the liquid), the off-gas circulation rate being many times its overall throughput across the contactor.

The new contactor offers two approaches to solving the $\mathrm{NO}_{\mathrm{X}}$ pollution problem. Where full recovery of nitric acid is desired, oxygen can be fed into the contactor to convert nitrous acid into nitric. This approach was demonstrated at LLNL. Alternately, in the proposed acidic urea process nitrous acid, as it forms from $\mathrm{NO}_{\mathrm{X}}$, would be converted to nitrogen, water and carbon dioxide.

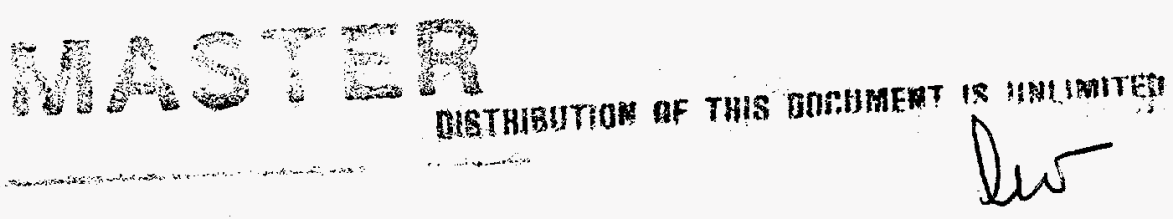




\section{Feasibility of common scale-up procedure for acidic urea and nitrous acid oxidation processes}

The acidic urea process chemistry is completely different from that of nitrous acid oxidation and since the only bench scale gas-liquid contactor became an integral part of the present MEO system, another one would be required to obtain the data necessary for the urea process scale-up. However, there is strong evidence that the acidic urea $\mathrm{DeNO}_{\mathrm{X}}$ scale-up should be no different from that for the nitrous acid conversion.

In general, when gas absorption process is accompanied by fast chemical reactions in liquid phase (they are usually fast or can be made fast by raising the temperature), the mass transfer becomes rate limiting and thus a basis for scale-up. A direct proof that the chemical reaction is fast with respect to the mass transfer, would be to show that the actual concentration $C$ of the gaseous reactant in the liquid phase is much lower than the equilibrium concentration $C^{*}$ predicted from the Henry's law. That would indicate that the gaseous reactant (e.g., oxygen for MEO) is consumed as soon as it is delivered. The dissolved oxygen concentration wasn't measured in the MEO experiments, but some relevant observations have been made. Whenever oxygen supply to the contactor was interrupted, nitrous acid in the catholyte would build-up and decompose releasing $\mathrm{NO}_{\mathrm{X}}$. The $\mathrm{NO}_{\mathrm{X}}$ was vented from the contactor via hose into the glass filled with water and formed increasingly strong jet hitting the bottom of the glass. Each opening of oxygen valve at that point would instantaneously reduce the jet strength or annihilate it completely. Such an immediate control would not be possible if the nitrous acid oxidation rate (or oxygen consumption) lagged behind the oxygen dissolution rate (delivery) and indicated that oxygen was consumed instantly. The observation is also consistent with Fig. 1 where the measured conversion efficiency is plotted as function of the product of the rotor tip speed and the gas circulation factor, the parameters directly affecting the oxygen transfer rather then the reaction rate. Strong effect of mass transfer (and thus, the mass transfer control) is seen to extend up to 98\% conversion. Only then the response to oxygen delivery weakens as the reaction in liquid phase essentially depleted of nitrous acid at that point slows enough to eventually take over as the rate controlling factor.

Similarly, regarding the acidic urea process, there is a sufficient body of evidence (cf. Warshaw, 1971) in the literature that absorption of $\mathrm{NO}_{\mathrm{X}}$ is accompanied by fast chemical reaction in the liquid phase and it is the gas-liquid contacting and mass transfer that usually need to be addressed to boost the overall absorption rate.

The mass transfer rate $r$ from the gaseous into the liquid phase is given by

$$
r=k a\left(C_{\mathrm{i}}-C\right), \quad \mathrm{kg} / \mathrm{m}^{3} \mathrm{~s}
$$

where $k$ is the overall mass transfer coefficient, $\mathrm{m} / \mathrm{s}, a$ is the specific interfacial (the bubbles' surface per volume of liquid) area, $\mathrm{m}^{-1}$ and $C_{\mathrm{i}}$ is the concentration of dissolved gas at the bubble interface on the liquid side, $\mathrm{kg} / \mathrm{m}^{3}$. 
The overall resistance $1 / k$ to mass transfer is a sum of the resistance $1 / k_{\mathrm{G}}=\delta_{\mathrm{G}} / D_{\mathrm{G}}$ inside the gas bubble and the resistance $1 / k_{\mathrm{L}}=\delta_{\mathrm{L}} / D_{\mathrm{L}}$ across the diffusion film $\delta_{\mathrm{L}}$ outside the bubble. Since diffusion coefficients $D_{\mathrm{G}}$ in gases are three to four orders of magnitude greater than $D_{\mathrm{L}}$ in liquids, the inside resistance is routinely ignored as negligible, $C_{\mathrm{i}} \approx C^{*}$ which is the gas solubility given by the Henry's law and $C \approx 0$. The mass transfer is, therefore, controlled on the liquid side through the liquid film mass transfer coefficient $k_{\mathrm{L}}$. Eq. (1) becomes

$$
r \approx k_{\mathrm{L}} a C^{*}
$$

Numerous experimental data (cf. Calderbank (1959)) [5] for agitated vessels indicate that $k_{\mathrm{L}}$ is a function of liquid phase diffusivity $D_{\mathrm{L}}$ and not of power input or gas rate and diffusivities of gases in water or aqueous solutions do not vary much. Most, including those of oxygen and nitrogen oxide, are within $D_{\mathrm{L}}=1.8 \times 10^{-9}-2.5 \times 10^{-9} \mathrm{~m}^{2} / \mathrm{s}$ range at room temperature [6]. Therefore, $k_{\mathrm{L}}$ is neither a scale-up variable, nor is it a factor affected by switching from oxygen to nitrogen oxide absorption. Furthermore, the solubility of oxygen and nitrogen oxide in water are also similar (e.g., $C^{*}=35 \mathrm{~g} / \mathrm{m}^{3}$ and $32 \mathrm{~g} / \mathrm{m}^{3}$ respectively at partial pressure of one atm and $50^{\circ} \mathrm{C} \mathrm{[6-7])} \mathrm{and} \mathrm{do} \mathrm{not} \mathrm{change} \mathrm{on} \mathrm{scale-up} \mathrm{which} \mathrm{leaves} \mathrm{the} \mathrm{interfacial} \mathrm{area} a$ in Eq. (2) as the only variable to be addressed in scale-up.

In his review of published data on scale-up for gas sparged mechanically agitated tanks with geometric similarity and constant gas/liquid volume ratio, Hughmark (1980) [8] concluded that the interfacial area $a$ was a function of a product $N^{a} D^{b}$, (or the impeller tip speed since $a$ and $b$ appeared to be close to unity) whose constancy preserves the constant gas-liquid mass transfer rate on scale-up. This scale-up rule does not necessarily address a separate issue of conversion which can be important whenever full utilization of pure gas (e.g., oxygen) or high scrubbing efficiency of harmful gas (e.g., $\mathrm{NO}_{\mathrm{X}}$ ) is required. In fact the rule is only accurate as long as gas bubbles are not noticeably depleted of the reactant consumed in the liquid phase which puts a limit on the reactant utilization and, ultimately, on a tank height. As long as the gaseous reagent, e.g., oxygen in the air used in waste water treatment or in aerobic fermentation, is inexpensive or harmless such "wasteful" practice is acceptable and even encouraged since it yields higher overall process rates. The approach must be different when pure oxygen is used or the gas is harmful. For example, very tall columns are employed to scrub $\mathrm{NO}_{\mathrm{X}}$ from off-gases even though mass transfer would have been much higher in gas sparged mechanically agitated tanks. The reason is low conversion of sparingly soluble gases per pass in the agitated tanks.

Self-aerated contactors, solve this dilemma and combine the best of mechanically agitated tanks and tall columns by recycling gas internally. As a function of the rotor tip speed or $N D$, the circulation rate $Q_{\mathrm{C}}$, unlike the gas throughput $Q_{\mathrm{T}}$, is not an independent parameter. Their ratio $F_{\mathcal{C}}$ $=Q_{\mathrm{C}} / Q_{\mathrm{T}}$, the circulation factor, serves as an equivalent of the column height assuring a specified conversion. Combined with $N D$, it can serve as a basis for the process scale-up where both, the 
rates and the conversions are the parameters to be preserved. The constancy of the product $I=$ $N D F_{c}$, the aeration index, assures the same conversion efficiency $E$ on scale-up. It has been decided to devise a common scale-up procedure based on the data already obtained.

\section{The scale-up Procedure}

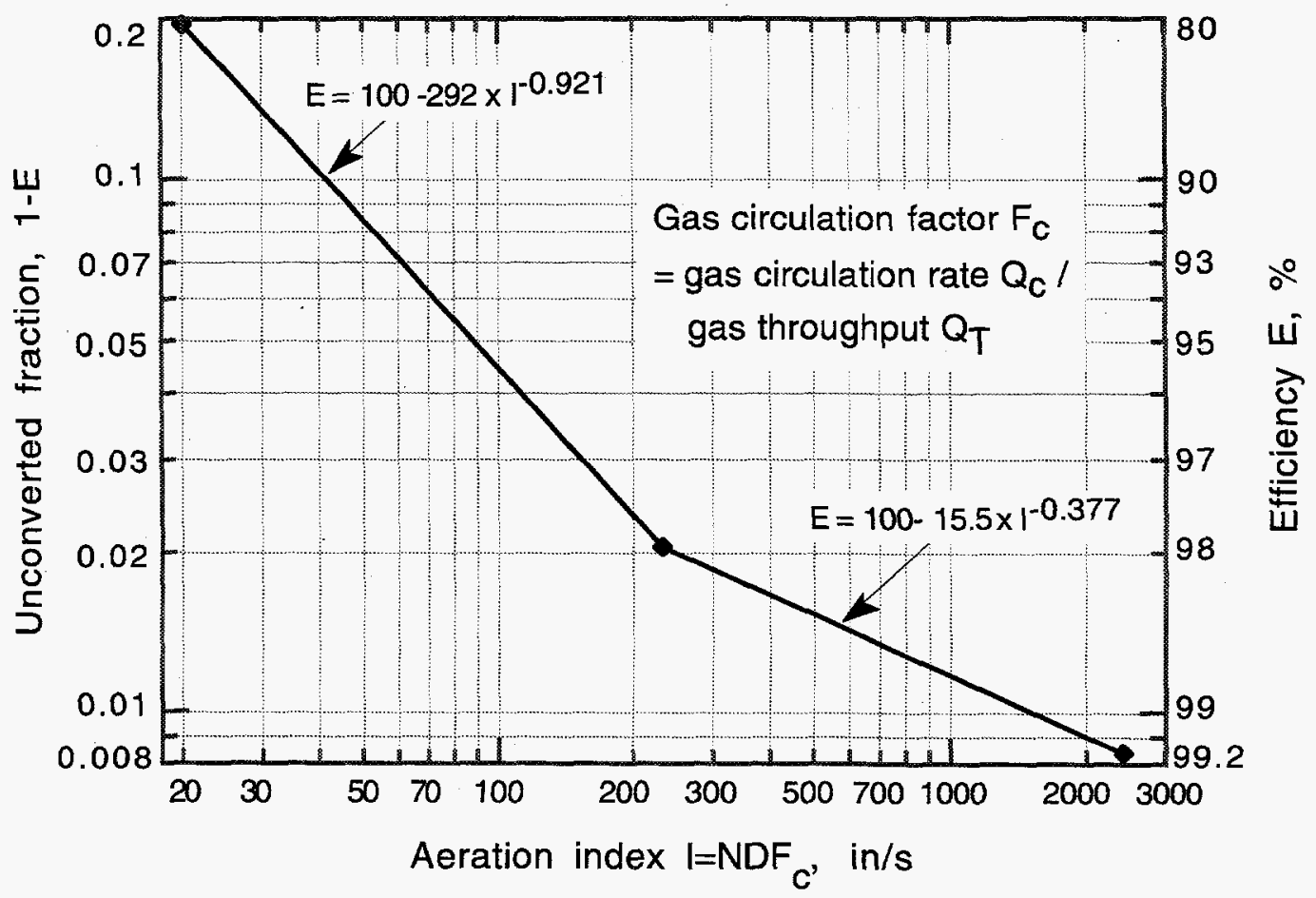

Fig. 1. Conversion efficiency as a function of aeration index

The fist step of the scale-up procedure is depicted in Fig. 1 where the aeration index $I$ can be determined as soon as the conversion efficiency $E$ is specified. Strong effect of mass transfer extending up to $98 \%$ conversion can be described by the relationship:

$$
E=100-292 I^{-0.921}
$$

As the reaction in liquid phase depleted of nitrous acid slows, the response to oxygen delivery weakens and the part of the curve corresponding to high conversion can be described by

$$
E=100-15.5 I^{-0.377}
$$

Note that the index $I$ is dimensional and care must be taken to keep the units consistent throughout the scale-up. The plot in Fig. 1 was obtained from the results of MEO experiments (see also the Appendix A) where nitrous acid generated within the catholyte was oxidized back into nitric acid with pure oxygen fed into the contactor:

$$
2 \mathrm{HNO}_{2}+\mathrm{O}_{2} \rightarrow 2 \mathrm{HNO}_{3}
$$


Table 1. MEO Experimental Results

\begin{tabular}{|c|c|c|c|c|c|c|c|c|c|c|}
\hline$N$ & {$\left[\mathrm{NO}_{\mathrm{x}}{ }^{\text {out }}\right.$} & $Q_{\mathrm{O} 2}{ }^{\mathrm{in}}$ & $E$ & $Q_{\mathrm{O} 2}{ }^{\text {con }}$ & $Q_{\mathrm{O} 2}{ }^{\text {out }}$ & $Q_{\mathrm{NOx}}{ }^{\text {ou }}$ & $Q_{\mathrm{T}}$ & $Q_{\mathrm{c}}$ & \multicolumn{2}{|c|}{$F_{\mathrm{c}} Q_{\mathrm{d}} Q_{\mathrm{T}} I=N D F_{\mathrm{c}}$} \\
\hline $\mathrm{s}^{-1}$ & $\%$ & $\mathrm{~L} / \mathrm{min}$ & $\%$ & $\mathrm{~L} / \mathrm{min}$ & $\mathrm{L} / \mathrm{min}$ & $\mathrm{L} / \mathrm{min}$ & $L / \min$ & $\mathrm{L} / \mathrm{min}$ & & $\mathrm{in} / \mathrm{s}$ \\
\hline 10 & 46.0 & 11.05 & 80.50 & 7.04 & 4.01 & 3.41 & 10.94 & 5.90 & 0.539 & 18.87 \\
\hline 12 & 10.5 & 11.60 & 97.97 & 8.57 & 3.03 & 0.36 & 7.67 & 40.16 & 5.237 & 220.0 \\
\hline 35 & 4.0 & 12.20 & 99.16 & 8.68 & 3.52 & 0.15 & 8.01 & 149.14 & 18.62 & 2281.0 \\
\hline
\end{tabular}

The conversion efficiency $E$ was defined twice, as a fraction of converted nitrous acid and as a ratio of oxygen consumed to that stoichiometrically required to oxidize all generated nitrous acid. As a function of current, the nitrous acid generation rate is well defined. Hence the maximum possible $\mathrm{NO}_{\mathrm{X}}$ flow rate (if all nitrous acid became $\mathrm{NO}_{\mathrm{X}}$ in the absence of conversion) was calculated as $Q_{\mathrm{NOx}}{ }^{\max }=(\mathrm{I} \cdot \mathrm{A}) / 2 \mathrm{~F}$ from the current $\mathrm{I}$, the Faraday number $\mathrm{F}$, and the Avogadro number A. At $\mathrm{I}=2000 \mathrm{amp}$ the electrochemical cell generated 13.9 standard liters of $\mathrm{NO}_{\mathrm{X}}$ per minute corresponding to $Q_{\mathrm{NOx}}{ }^{\max }=17.5 \mathrm{~L} / \mathrm{min}$ at $70^{\circ} \mathrm{C}$, the temperature of $\mathrm{MEO}$ experiments. Similarly, the oxygen feed rate $Q_{\mathrm{O} 2}{ }^{\mathrm{in}}$ is shown in Table 1 for $70^{\circ} \mathrm{C}$. The efficiency $E$ was calculated from the expression (10A) obtained by $Z$. Chiba:

$$
E=\frac{1-\left[\mathrm{NO}_{\mathrm{X}}{ }^{\mathrm{out}}\right]\left(1+\frac{Q_{\mathrm{O}} 2^{\mathrm{in}}}{Q_{\mathrm{NOx}}{ }^{\max }}\right)}{1-1.5\left[\mathrm{NO}_{\mathrm{X}}{ }^{\text {out }}\right]}
$$

where the $\mathrm{NO}_{\mathrm{x}}$ concentration $\left[\mathrm{NO}_{\mathrm{x}}{ }^{\text {out }}\right]$ in the off-gas leaving the contactor and the oxygen flow rate $Q_{\mathrm{O} 2}{ }^{\text {in }}$ entering the contactor were measured. More detail on the experiments and the full derivation of (10A) are given in Appendix A. Equations (5A), (7A) and (8A) in the Appendix were used to calculate respectively $Q_{\mathrm{NOx}}{ }^{\text {out }}, Q_{\mathrm{O} 2}{ }^{\text {out }}$ and $Q_{\mathrm{O} 2}{ }^{\text {con }}$ in Table 1 . For the average gas throughput $Q_{\mathrm{T}}$ across the converter the expression below was employed:

$$
Q_{\mathrm{T}}=\frac{Q_{\mathrm{O} 2}{ }^{\mathrm{in}}+Q_{\mathrm{O} 2}{ }^{\text {out }}}{2}+Q_{\mathrm{NOx}}{ }^{\text {out }}
$$

The second step of the scale-up procedure is associated with Fig. 2 adopted from the earlier publication by Zundelevich (1979) [4]. It represents generalization of experimental data on gas circulation capacity of variable size geometrically similar aerators (see Fig. 1B) expressed in terms of two dimensionless groups, the Euler number Eu and the rotor head coefficient $\mathrm{C}_{\mathrm{H}}$. All that is required to use Fig. 2 is the aeration index $I$ (obtained from Fig. 1 once the conversion efficiency $E$ is specified), the off-gas throughput $Q_{\mathrm{T}}$ across the contactor, and the dimensionless submergence $h=H / D$ (which also provides a convenient way to maintain the relationship between the aerator and the contactor sizes on scale-up). By selecting $\mathrm{C}_{\mathrm{H}}$ from an approximate interval of 0.3 to 0.9, where operation is most economical, $\mathrm{Eu}$ and $\mathrm{EuC}_{\mathrm{H}}$ are obtained and used 
to determine the aerator rotor diameter $D$, the rotation speed $N$, the required power input $P$ and the gas circulation rate $Q_{\mathrm{C}}$. A detailed explanation of the above scale-up procedure can be found in Appendix B. A few examples of predicted gas circulation capacity are shown in Fig.3.

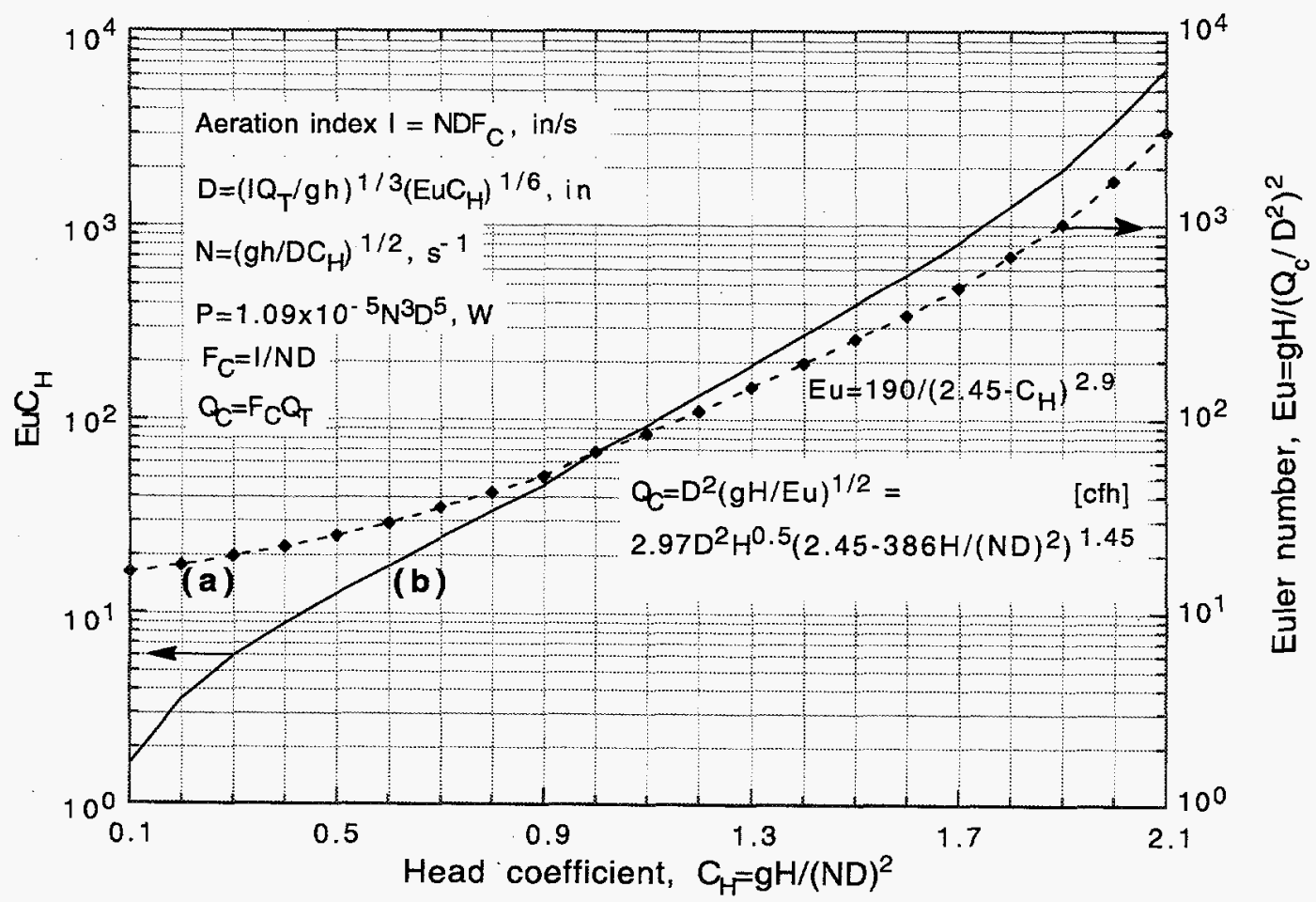

Fig. 2. Dimensionless performance characteristics of turbo-aerator (a)-Experimental data plotted as Eu vs. $C_{H}[4]$; (b)-EuC $C_{H}$ vs. $C_{H}$

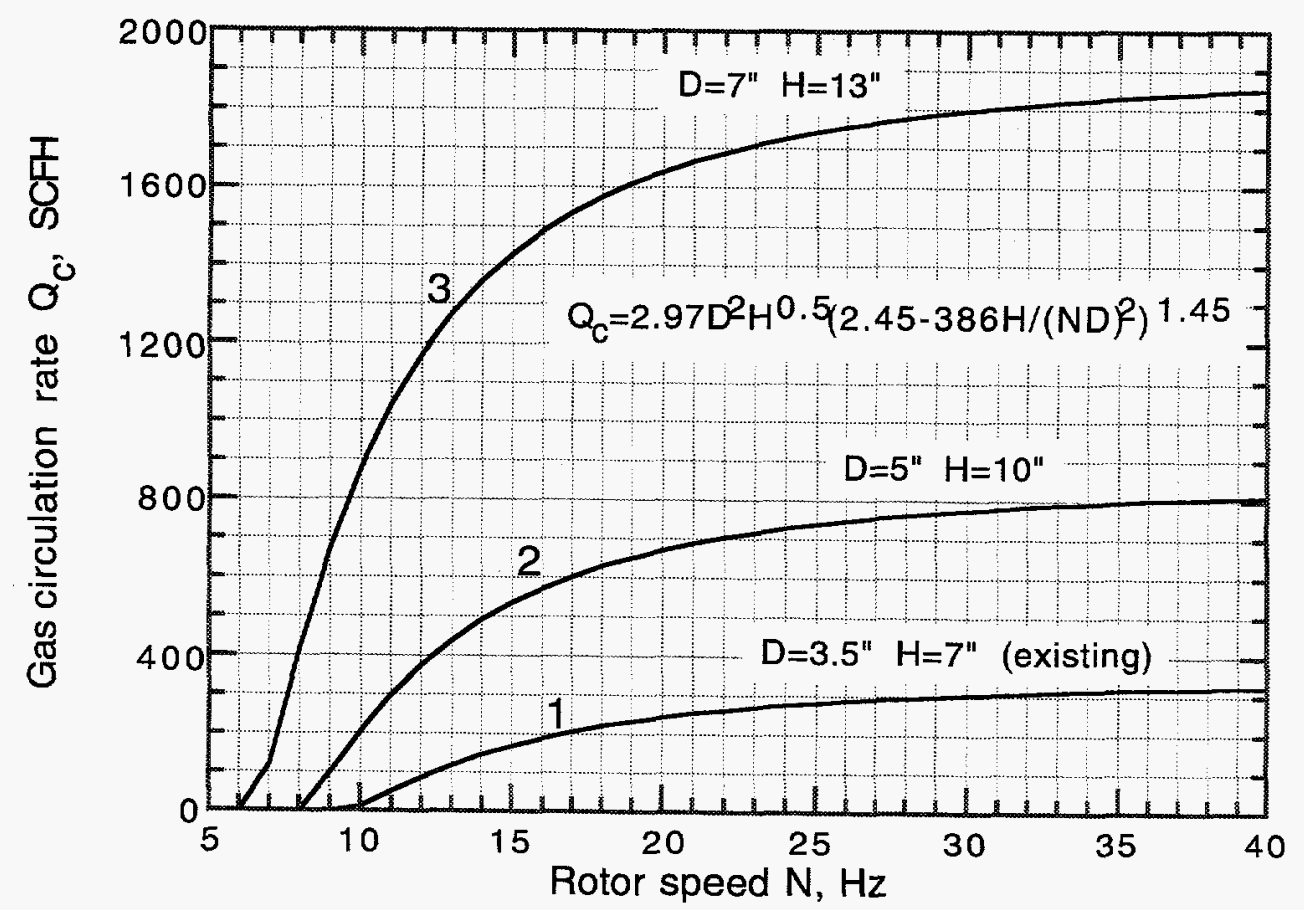

Fig. 3 Variation of gas circulation rate $Q_{c}$ on scale-up 


\section{Scale-up of gas-liquid contactor for acidic urea $\operatorname{DeNO}_{\mathbf{x}}$}

MWMF System Design Requirements for the Experimental Off-Gas Treatment call for a system capable of handling up to $10 \mathrm{~m}^{3}$ of off-gas per hour. Assuming conversion efficiency of $98.5 \%$ and the geometry similar to the existing bench-scale converter, the following design steps can be accomplished using only Figs. 1 and 2.

Given: $Q_{T}=10 \mathrm{~m}^{3} / \mathrm{h}=353 \mathrm{cfh}=170 \mathrm{in}^{3} / \mathrm{s}, \quad E=98.5 \%, \quad h=1.9$

Step 1. From Fig.1: $I=N D F_{c}=600 \mathrm{in} / \mathrm{s}$

Step 2. From Fig.2: for $\mathrm{C}_{\mathrm{H}}=0.3 \mathrm{Eu}=20$ and $\mathrm{EuC}_{\mathrm{H}}=6$.

Using equations (14B) and (15B) shown in Fig. 2 obtain: $D=6.98 ", N=18.7 \mathrm{~s}^{-1}$.

Use standard motor with $1140 \mathrm{rpm}=19 \mathrm{~Hz}$ and $\mathrm{D}=7^{\prime \prime}$

Using equation (8B), power input: $P=1.09 \times 10^{-5} N^{3} D^{5}=1.09 \times 10^{-5} 19^{3} 7^{5}=1258 \mathrm{~W}$

$F_{C}=I / N D=600 /(19 \times 7)=4.51$

$Q_{c}=353 \cdot 4.51=1592 \mathrm{cfh}$

From Fig.3 (curve 3): maximum $Q_{c}=1610 \mathrm{cfh}$ at $N=19 \mathrm{~Hz}$.

Step 3. Aerator submergence $H=h D=1.9 \times 7=13^{\prime \prime}$. By setting the distance to the tank bottom equal to the aerator rotor diameter $7 "$, the total liquid fill height $13^{\prime \prime}+7 "=20 "$. Select tank diameter $T=22$ " and the tank height $H_{\mathrm{T}}=33^{\prime \prime}$.

Note, that from the power consumption standpoint the optimum design would have required $\mathrm{C}_{\mathrm{H}}$ $=0.9$ [4] (see also Appendix B). Proceeding with this option:

Step 2. From Fig.2: for $\mathrm{C}_{\mathrm{H}}=0.9 \mathrm{Eu}=53$ and $\mathrm{EuC}_{\mathrm{H}}=48$.

Using equations in Fig. 2 obtain: $D=9.86 ", N=9.1 \mathrm{~s}^{-1}=545 \mathrm{rpm}$.

Power input: $P=1.0913 \times 10^{-5} N^{3} D^{5}=1.0913 \times 10^{-5} 9.1^{3} \times 9.86^{5}=764 \mathrm{~W}$

$F_{C}=I / N D=600 /(9.1 \times 9.87)=6.7$

$Q_{c}=353 \times 6.7=2362 \mathrm{cfh}$

Since there is no small motors with $545 \mathrm{rpm}$, a gear box would be required.

Step 3. Aerator submergence $H=h D=1.9 \times 9.86=18.75^{\prime \prime}$. By setting the distance to the tank bottom equal to the aerator rotor diameter $9.86 "$, the total liquid fill height $18.75^{\prime \prime}+9.86 "=28.6^{\prime \prime}$. The resulting tank diameter $T=30^{\prime \prime}$ and the tank height $H_{\mathrm{T}}=45^{\prime \prime}$.

With a simple FORTRAN code (given in Appendix C) performing essentially the same steps, a table of design options like the one below can be generated and reviewed.

PROGRAM AERATOR SCALE-UP

Gas Throughput $Q_{\mathrm{T}}=353.0 \mathrm{cfh}$

Dimensionless Submergence $h=H / D=1.90$ 


\begin{tabular}{|c|c|c|c|c|c|c|c|c|}
\hline $\mathrm{C}_{\mathrm{H}}$ & $\begin{array}{l}V_{\text {liq }} \\
\text { liter }\end{array}$ & $\begin{array}{l}N \\
\text { rpm }\end{array}$ & $\underset{\mathrm{cfh}}{Q_{\mathrm{C}}}$ & $\begin{array}{l}T \\
\text { in }\end{array}$ & $\begin{array}{c}H_{\mathrm{T}} \\
\text { in }\end{array}$ & $\begin{array}{c}F c \\
--\end{array}$ & $\begin{array}{l}D \\
\text { in }\end{array}$ & $\begin{array}{l}P \\
W\end{array}$ \\
\hline \multicolumn{4}{|c|}{ Aeration Index $I=300.0 \mathrm{in} / \mathrm{s}$} & \multicolumn{4}{|c|}{ Efficiency $E=98.14 \%$} & \\
\hline 0.2 & 48.8 & 1610.9 & 775.2 & 16.0 & 24.0 & 2.20 & 5.09 & 719.6 \\
\hline 0.3 & 63.8 & 1257.7 & 907.8 & 17.5 & 26.3 & 2.57 & 5.57 & 535.9 \\
\hline 0.4 & 79.0 & 1051.2 & 1011.7 & 18.8 & 28.2 & 2.87 & 5.97 & 446.2 \\
\hline 0.5 & 94.9 & 911.8 & 1096.9 & 20.0 & 30.0 & 3.11 & 6.35 & 395.8 \\
\hline 0.6 & 112.2 & 809.5 & 1168.6 & 21.2 & 31.7 & 3.31 & 6.72 & 366.0 \\
\hline 0.7 & 131.4 & 730.0 & 1229.5 & 22.3 & 33.5 & 3.48 & 7.08 & 349. \\
\hline 0.8 & 153.0 & 665.8 & 1281.4 & 23.5 & 35.2 & 3.63 & 7.45 & 341 . \\
\hline 0.9 & 177.7 & 612.2 & 1325.7 & 24.7 & 37.0 & 3.76 & 783 & 340 . \\
\hline
\end{tabular}

Aeration Index $I=600.0 \mathrm{in} / \mathrm{s} \quad$ Efficiency $E=98.57 \%$

$\begin{array}{rrrrrrrrr}0.2 & 97.6 & 1435.2 & 1381.2 & 20.2 & 30.3 & 3.91 & 6.41 & 1615.3 \\ 0.3 & 127.6 & 1120.5 & 1617.6 & 22.1 & 33.1 & 4.58 & 7.01 & 1202.9 \\ 0.4 & 157.9 & 936.6 & 1802.7 & 23.7 & 35.6 & 5.11 & 7.53 & 1001.6 \\ 0.5 & 189.9 & 812.4 & 1954.6 & 25.2 & 37.8 & 5.54 & 8.00 & 888.4 \\ 0.6 & 224.5 & 721.2 & 2082.2 & 26.7 & 40.0 & 5.90 & 8.46 & 821.7 \\ 0.7 & 262.8 & 650.4 & 2190.7 & 28.1 & 42.1 & 6.21 & 8.92 & 783.7 \\ 0.8 & 306.0 & 593.1 & 2283.3 & 29.6 & 44.3 & 6.47 & 9.38 & 766.0 \\ 0.9 & 355.3 & 545.4 & 2362.2 & 31.1 & 46.6 & 6.69 & 9.86 & 764.3\end{array}$

Aeration Index $I=1200.0 \mathrm{in} / \mathrm{s} \quad$ Efficiency $E=98.90 \%$

$\begin{array}{rrrrrrrrr}0.2 & 195.1 & 1278.6 & 2461.1 & 25.4 & 38.2 & 6.97 & 8.08 & 3625.9 \\ 0.3 & 255.3 & 998.3 & 2882.2 & 27.8 & 41.7 & 8.16 & 8.83 & 2700.2 \\ 0.4 & 315.8 & 834.4 & 3212.0 & 29.9 & 44.8 & 9.10 & 9.48 & 2248.4 \\ 0.5 & 379.7 & 723.8 & 3482.7 & 31.8 & 47.6 & 9.87 & 10.08 & 1994.2 \\ 0.6 & 448.9 & 642.5 & 3710.0 & 33.6 & 50.4 & 10.51 & 10.66 & 1844.5 \\ 0.7 & 525.6 & 579.4 & 3903.4 & 35.4 & 53.1 & 11.06 & 11.24 & 1759.3 \\ 0.8 & 611.9 & 528.4 & 4068.4 & 37.2 & 55.9 & 11.53 & 11.82 & 1719.5 \\ 0.9 & 710.6 & 485.9 & 4209.0 & 39.1 & 58.7 & 11.92 & 12.43 & 1715.7\end{array}$

Compared to the actually selected design (at $\mathrm{C}_{\mathrm{H}}=0.3$ ), the "optimum" version at $\mathrm{C}_{\mathrm{H}}=0.9$ saves power but requires motor gear and increases tank volume (to accommodate larger aerator without wall effects) which is hardly justified on a small scale. However, optimum design would be a logical choice for large and deep commercial units consuming tens or hundreds of kilowatts of power. As the scale (and the submergence) keeps increasing, a point is usually reached where a cascade of smaller tanks becomes economically preferable to a single large and deep unit.

\section{Scale-up of gas-liquid contactor for MEO nitrous acid converter}

MWMF System Design Requirements for Mediated Electrochemical Oxidation call for 12,500 A integrated cell current, a scale factor of 6.25 over the present 2,000 A. The average gas throughput $Q_{\mathrm{T}}$ can be estimated, as before, with the expression (6). For $\mathrm{I}=12,000 \mathrm{~A} Q \mathrm{O} 2^{\text {sto }}=$ $1 / 2 Q_{\mathrm{NOx}}{ }^{\max }=(\mathrm{I} \cdot \mathrm{A}) / 4 \mathrm{~F}=44.2 \mathrm{~L} / \mathrm{min}(\mathrm{stp})$ or $54.7 \mathrm{~L} / \mathrm{min}$ at $70^{\circ} \mathrm{C}$. Assuming conversion 
efficiency of $98.5 \%$ and $30 \%$ excess oxygen (for the sake of $Q_{\mathrm{T}}$ estimate), we obtain $Q_{\mathrm{O} 2}{ }^{\mathrm{con}}=$ $E Q_{\mathrm{O} 2}{ }^{\text {sto }}=53.9 \mathrm{~L} / \mathrm{min}, Q_{\mathrm{NOx}}{ }^{\text {out }}=(1-E) Q_{\mathrm{NOx}}{ }^{\max }=1.6 \mathrm{~L} / \mathrm{min}$ and $Q_{\mathrm{O} 2}{ }^{\text {in }}=53.9 \times 1.3=70$ $\mathrm{L} / \mathrm{min}$. Then from (6):

$$
Q_{\mathrm{T}}=\frac{Q_{\mathrm{O} 2}{ }^{\text {in }}+Q_{\mathrm{O} 2}{ }^{\text {out }}}{2}+Q_{\mathrm{NOx}}{ }^{\text {out }}=\frac{70+16.1}{2}+1.6=44.7 \mathrm{~L} / \mathrm{min}
$$

Assuming $Q_{\mathrm{T}}=45 \mathrm{~L} / \mathrm{min}=95.3 \mathrm{cfh}$ and the geometry similar to the existing bench-scale converter, the following design options can be generated and reviewed.

Gas Throughput $Q_{\mathrm{T}}=95.3 \mathrm{cfh}$

Dimensionless Submergence $h=H / D=1.90$

$\begin{array}{lllllrrrr}\mathrm{C}_{\mathrm{H}} & V_{\text {liq }} & N & Q_{\mathrm{C}} & T & H_{\mathrm{T}} & F C & D & P \\ -- & \text { liter } & \text { rpm } & \text { cfh } & \text { in } & \text { in } & -- & \text { in } & \text { W }\end{array}$

\begin{tabular}{crcccccr} 
Aeration & Index $I=300.0 \mathrm{in} / \mathrm{s}$ & \multicolumn{7}{c}{ Efficiency $E=98.14 \%$} \\
13.2 & 2003.8 & 260.3 & 10.4 & 15.5 & 2.73 & 3.29 & 156.2 \\
17.2 & 1564.4 & 304.8 & 11.3 & 17.0 & 3.20 & 3.60 & 116.3 \\
21.3 & 1307.6 & 339.7 & 12.2 & 18.2 & 3.56 & 3.86 & 96.9 \\
25.6 & 1134.2 & 368.4 & 12.9 & 19.4 & 3.87 & 4.11 & 85.9 \\
30.3 & 1006.9 & 392.4 & 13.7 & 20.5 & 4.12 & 4.34 & 79.5 \\
35.5 & 908.0 & 412.9 & 14.4 & 21.6 & 4.33 & 4.58 & 75.8 \\
41.3 & 828.1 & 430.3 & 15.2 & 22.7 & 4.52 & 4.81 & 74.1 \\
48.0 & 761.5 & 445.2 & 15.9 & 23.9 & 4.67 & 5.06 & 73.9
\end{tabular}

\begin{tabular}{crcccccc} 
Aeration Index $I=600.0 \mathrm{in} / \mathrm{s}$ & \multicolumn{6}{c}{ Efficiency $E=98.57 \%$} \\
26.3 & 1785.2 & 463.8 & 13.1 & 19.6 & 4.87 & 4.14 & 350.6 \\
34.5 & 1393.8 & 543.2 & 14.3 & 21.4 & 5.70 & 4.53 & 261.1 \\
42.6 & 1164.9 & 605.3 & 15.3 & 23.0 & 6.35 & 4.86 & 217.4 \\
51.3 & 1010.5 & 656.4 & 16.3 & 24.4 & 6.89 & 5.17 & 192.8 \\
60.6 & 897.0 & 699.2 & 17.2 & 25.8 & 7.34 & 5.47 & 178.4 \\
71.0 & 809.0 & 735.6 & 18.2 & 27.2 & 7.72 & 5.77 & 170.1 \\
82.6 & 737.8 & 766.7 & 19.1 & 28.7 & 8.05 & 6.06 & 166.3 \\
95.9 & 678.5 & 793.2 & 20.1 & 30.1 & 8.32 & 6.37 & 165.9
\end{tabular}

Aeration Index $I=1200.0 \mathrm{in} / \mathrm{s} \quad$ Efficiency $E=98.90 \%$

$\begin{array}{rrrrrrrrr}0.2 & 52.7 & 1590.4 & 826.4 & 16.4 & 24.7 & 8.67 & 5.22 & 787.1 \\ 0.3 & 68.9 & 1241.7 & 967.9 & 18.0 & 27.0 & 10.16 & 5.71 & 586.1 \\ 0.4 & 85.3 & 1037.9 & 1078.6 & 19.3 & 29.0 & 11.32 & 6.13 & 488.1 \\ 0.5 & 102.5 & 900.2 & 1169.5 & 20.5 & 30.8 & 12.27 & 6.52 & 432.9 \\ 0.6 & 121.2 & 799.2 & 1245.9 & 21.7 & 32.6 & 13.07 & 6.89 & 400.4 \\ 0.7 & 141.9 & 720.7 & 1310.8 & 22.9 & 34.3 & 13.75 & 7.26 & 381.9 \\ 0.8 & 165.2 & 657.3 & 1366.2 & 24.1 & 36.1 & 14.34 & 7.64 & 373.3 \\ 0.9 & 191.9 & 604.4 & 1413.4 & 25.3 & 37.9 & 14.83 & 8.03 & 372.4\end{array}$

Since it is very desirable to reduce the overall nitric acid inventory in the MEO system, there is a strong incentive to keep $V$ liq and, therefore, the contactor size at a minimum. Given the low gas throughput, that is easily done, indicating that the MEO contactor is going to be much smaller 
then the acidic urea $\mathrm{DeNO}_{\mathrm{X}}$ contactor. Thus the earlier arguments favoring low $\mathrm{C}_{\mathrm{H}}$ for small scale remain applicable. A suitable design, among the above options, can be located in the vicinity of the lines:

\begin{tabular}{|c|c|c|c|c|c|c|c|c|}
\hline $\mathrm{C}_{\mathrm{H}}$ & $V_{\text {liq }}$ & $N$ & $Q_{\mathrm{C}}$ & $T$ & $H_{\mathrm{T}}$ & $F c$ & $D$ & $\begin{array}{l}P \\
\mathrm{~W}\end{array}$ \\
\hline$\overline{0-}$ & $\begin{array}{l}\text { liter } \\
263\end{array}$ & rpm & $\begin{array}{c}\text { cfh } \\
4638\end{array}$ & in & in & $\overline{87}$ & in & $\begin{array}{r}W \\
350\end{array}$ \\
\hline 0.3 & 34.5 & 1393.8 & 543.2 & 14.3 & 21.4 & 5.70 & 4.53 & 261 \\
\hline
\end{tabular}

By selecting $D=4.5^{\prime \prime}, H=9^{\prime \prime}, T=14^{\prime \prime}, H_{\mathrm{T}}=21^{\prime \prime}$ and $N=28.75 \mathrm{~s}^{-1}=1725 \mathrm{rpm}$ (using standard motor), the maximum power consumption $P=1.0913 \times 10^{-5} N^{3} D^{5}=1.0913 \times 10^{-5}$ $28.75^{3} \times 4.5^{5}=478 \mathrm{~W}$. Hence $0.75 \mathrm{hp}$ motor would be adequate. From Eq. (5B) the maximum gas circulation rate $Q_{\mathrm{C}}=582 \mathrm{cfh}, F c=582 / 95.3=6.1$ and the aeration index $I=$ $6.1 \times 4.5 \times 28.75=789 \mathrm{in} / \mathrm{s}$. From Eq. (4) the maximum efficiency $E=98.75 \%$. Comparing Vliq $=35 \mathrm{~L}$ for this unit with $V_{\text {liq }}=20 \mathrm{~L}$ in the existing unit it can be concluded that the adequate converter for 2,000 A cell could have been made considerably smaller.

\section{Appendix A. Calculation of nitrous acid conversion efficiency from the results of the MEO experiments}

On the cathode side of the MEO cell the electrolyte ( $\approx 6$ molar nitric acid) is reduced to nitrous acid via the reaction:

$$
\mathrm{HNO}_{3}+2 \mathrm{e}^{-}+2 \mathrm{H}^{+} \rightarrow \mathrm{HNO}_{2}+\mathrm{H}_{2} \mathrm{O}
$$

If the nitrous acid is allowed to build up, it will decompose via the reaction:

$$
\mathrm{HNO}_{2} \rightarrow 1 / 2 \mathrm{NO}_{2}+1 / 2 \mathrm{NO}+1 / 2 \mathrm{H}_{2} \mathrm{O}
$$

Besides producing large amount of $\mathrm{NO}_{\mathrm{X}}$ (one mole of $\mathrm{HNO}_{2}$ produces one mole of $\mathrm{NO}_{\mathrm{X}}$ as an equimolar mixture of $\mathrm{NO}_{2}$ and $\mathrm{NO}$ ), this also causes net nitric acid loss to the system and could trigger generation of hydrogen at the cathode once the nitric acid concentration drops below about 2 molar.

To prevent all of the above from happening, the catholyte is continually circulated through the Nitrous Acid Converter, as shown in Fig. 1A, where the nitrous acid is oxidized back into nitric via the reaction:

$$
\mathrm{HNO}_{2}+1 / 2 \mathrm{O}_{2} \rightarrow \mathrm{HNO}_{3}
$$




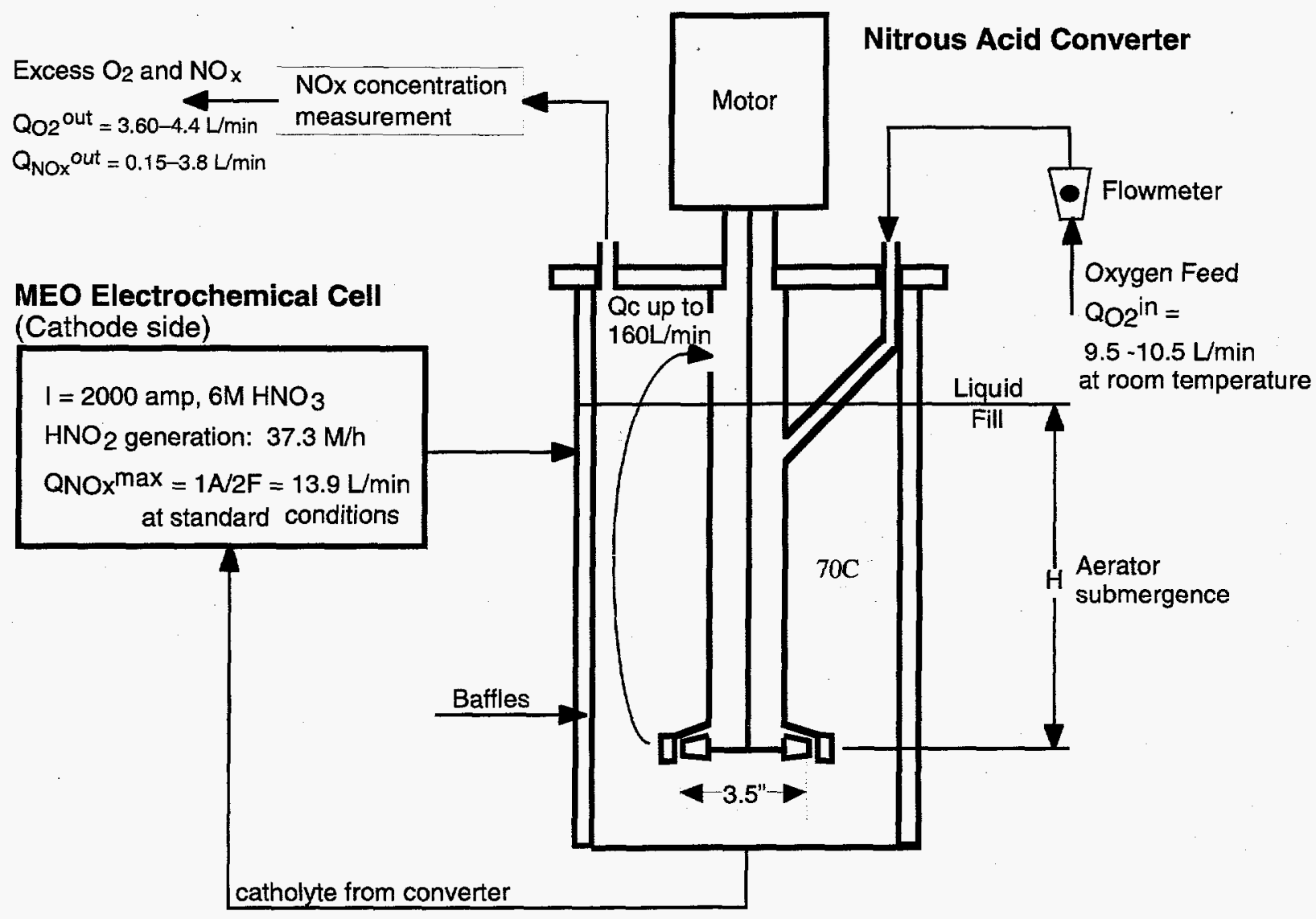

Fig. 1A. Nitrous acid conversion experiment schematic

The Nitrous Acid Converter is the gas-liquid contactor described earlier, into which oxygen is fed at ambient pressure and temperature. The oxygen feed rate $\mathrm{QO}_{2}{ }^{\mathrm{in}}$, measured by the flow meter, is kept slightly above $Q_{\mathrm{O} 2}{ }^{\text {sto }}$, the stoichiometric oxygen requirement for complete oxidation of all nitrous acid being generated. As a function of the sell current $\mathrm{I}$, the nitrous acid generation rate is fully predictable and so is its $\mathrm{NO}_{\mathbf{x}}$ equivalent $Q_{\mathrm{NOx}}{ }^{\max }$, the maximum $\mathrm{NO}_{\mathbf{X}}$ generation rate in the absence of $\mathrm{HNO}_{3}$ regeneration:

$$
Q_{\mathrm{NOx}}{ }^{\max }=(\mathrm{IA}) / 2 \mathrm{~F},
$$

where $\mathrm{A}=22.4 \mathrm{~L} / \mathrm{mole}$ is Avogadro number and $\mathrm{F}=96500$ coulomb/mole is Faraday number. The conversion efficiency $E$ was defined two ways, as a fraction of converted nitrous acid (potential $\mathrm{NO}_{\mathrm{X}}$ ) and as a ratio of consumed oxygen $Q_{\mathrm{O} 2}{ }^{\text {con }}$ to that stoichiometrically required to oxidize all nitrous acid:

$$
E=1-\frac{Q_{\mathrm{NOx}}{ }^{\text {out }}}{Q_{\mathrm{NOx}}{ }^{\max }}=\frac{Q_{\mathrm{O} 2}{ }^{\text {con }}}{Q_{\mathrm{O} 2}{ }^{\text {sto }}}
$$

The unknown quantity $Q_{\mathrm{NOX}}{ }^{\text {out }}$ in (5A), the rate of unconverted $\mathrm{NO}_{\mathrm{X}}$ release, can be expressed through its measured concentration $\left[\mathrm{NO}_{\mathrm{X}}{ }^{\text {out }}\right]$ in a mixture of unconverted $\mathrm{NO}_{\mathrm{X}}$ and the unused oxygen which constitutes the complete MEO off-gas on the cathode side: 


$$
Q_{\mathrm{NOx}}{ }^{\text {out }}=\left[\mathrm{NO}_{\mathrm{X}}{ }^{\text {out }}\right]\left(Q_{\mathrm{NOx}}{ }^{\text {out }}+Q_{\mathrm{O} 2}{ }^{\text {out }}\right)
$$

Defining the rate of release of unused oxygen in $(6 \mathrm{~A})$ as

$$
Q_{\mathrm{O} 2}{ }^{\text {out }}=Q_{\mathrm{O} 2}{ }^{\text {in }}-Q_{\mathrm{O} 2}{ }^{\text {con }} \text {, }
$$

and expressing $Q_{\mathrm{O} 2}{ }^{\text {con }}$ in (7A) through (5A) and the stoichiometric relationship $Q_{\mathrm{O} 2}{ }^{\text {sto }}=$ $1 / 2 Q_{\text {NOx }}{ }^{\max }$

$$
Q_{\mathrm{O} 2}{ }^{\mathrm{con}}=E Q_{\mathrm{O} 2}{ }^{\text {sto }}=1 / 2 E Q_{\mathrm{NOx}}{ }^{\max },
$$

we have from (6A-8A) for $Q_{\mathrm{NOx}}{ }^{\text {out: }}$

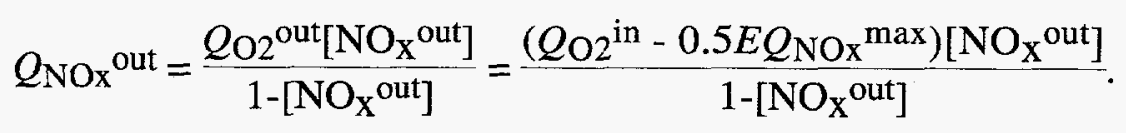

Substituting (9A) into (5A)

$$
E=1-\frac{\left(Q_{\mathrm{O} 2^{\text {in }}}-0.5 E Q_{\mathrm{NOx}}{ }^{\mathrm{max}}\right)\left[\mathrm{NO}_{\mathrm{X}}{ }^{\text {out }}\right]}{\left(1-\left[\mathrm{NO}_{\mathrm{x}}{ }^{\mathrm{out}}\right]\right) Q_{\mathrm{NOx}}{ }^{\max }},
$$

and solving for $E$, the expression (10A) used to calculate nitrous acid conversion efficiency during MEO experiments is obtained:

$$
E=\frac{1-\left[\mathrm{NO}_{\mathrm{x}}^{\mathrm{out}}\right]\left(1+\frac{Q_{\mathrm{O} 2}{ }^{\mathrm{in}}}{Q_{\mathrm{NOx}}{ }^{\mathrm{max}}}\right)}{1-1.5\left[\mathrm{NO}_{\mathrm{x}}{ }^{\mathrm{out}}\right]}
$$

\section{Appendix B. Development of the scale-up procedure for self-inducting turbo aerators}

As a part of theoretical and experimental investigation of self-inducting turbo aerator performance, Y. Zundelevich (1979) [4], demonstrated a unique relationship between two dimensionless groups, the Euler number

$$
\mathrm{Eu}=\frac{g H}{\left(Q_{c} / D^{2}\right)^{2}}
$$

and the head coefficient

$$
\mathrm{C}_{\mathrm{H}}=\frac{g H}{(N D)^{2}},
$$

which laid out a basis for the scale-up of geometrically similar aerators. He also formed optimality criterion $Q_{c} H / P$ [4] from the key aerator characteristics such as its gas inducing capacity $Q_{C}$ and the power consumption $P$ at a given submergence $H$ and showed that within practically important $\mathrm{C}_{\mathrm{H}}$ range where $Q_{c} H / P$ was high, it was another unique function of $\mathrm{C}_{\mathrm{H}}$. The design of the aerator (see Fig. 1B) intended for nitrous acid conversion and for acidic urea 
DeNO $\mathrm{x}_{\mathrm{X}}$ was perfected earlier $[3,4]$ on the basis of the above criterion which attains maximum value of $Q_{c} H / P=0.039 \frac{\mathrm{m}^{4}}{\mathrm{Wh}}=4.5 \frac{\mathrm{ft}^{4}}{\mathrm{Wh}}$ at $\mathrm{C}_{\mathrm{H}}=0.9$.

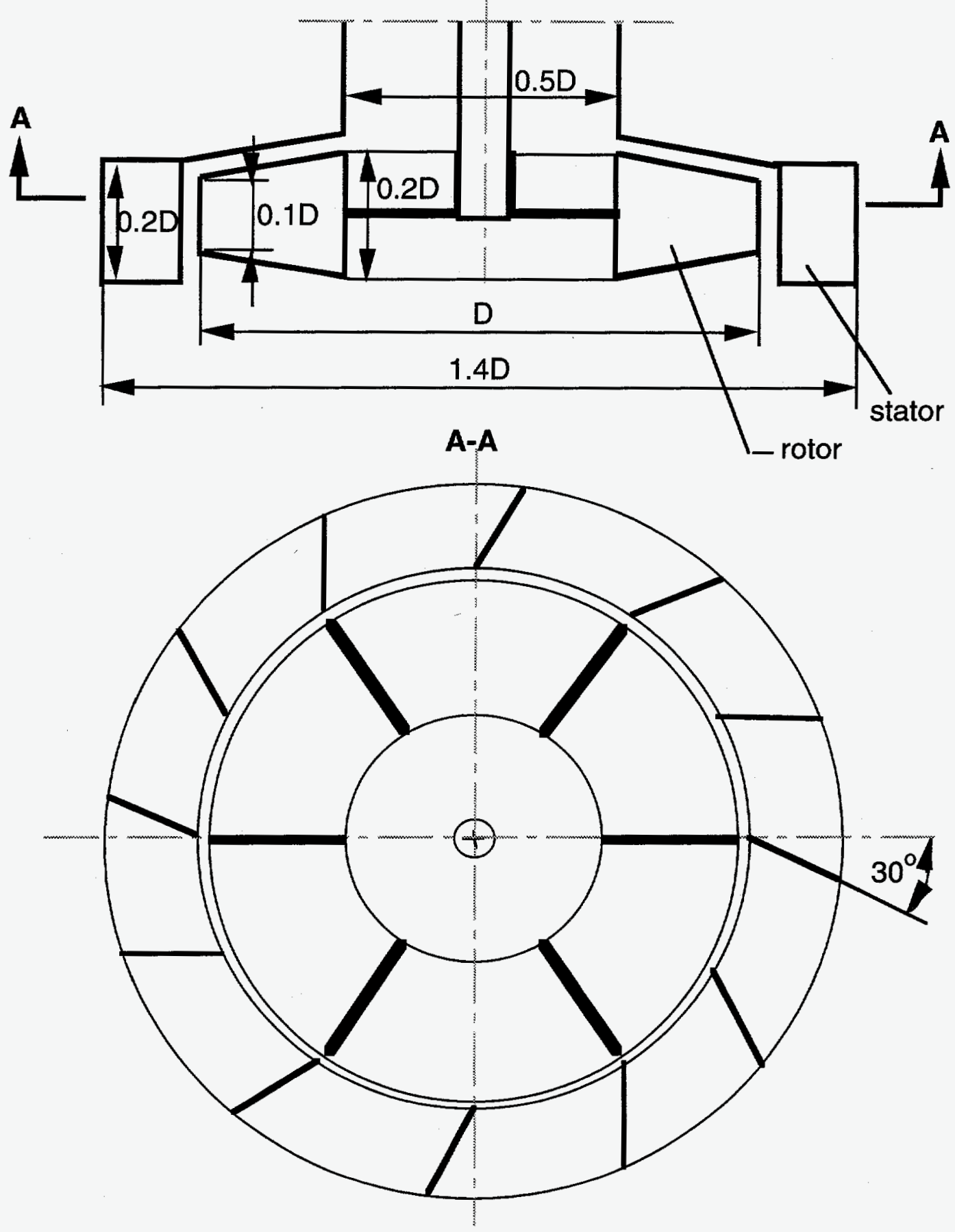

Fig. 1B. Turbo aerator geometry

The $\mathrm{Eu}-\mathrm{C}_{\mathrm{H}}$ relationship for this design, based on the experiments with three aerator diameters $D$ and covering broad ranges of rotational speed $N$ and submergence $H$ [4], is shown in Fig. 2 together with its analytical expression: 


$$
\mathrm{Eu}=\frac{190}{\left(2.45-\mathrm{C}_{\mathrm{H}}\right)^{2.9}}
$$

It relates the main aerator characteristic, its gas inducing capacity $Q_{c}$, to the three primary operational/design parameters $D, N$ and $H$. Solving (1B) for $Q_{c}$

$$
Q_{C}=D^{2} \sqrt{\frac{g H}{\mathrm{Eu}}}
$$

or substituting (3B) into (4B)

$$
Q_{c}=2.97 D^{2} \sqrt{H}\left(2.45-\frac{386 H}{(N D)^{2}}\right)^{1.45},
$$

two equivalent equations predicting the gas inducing capacity $Q_{c}$ are obtained. In Eq. (4B) any consistent units can be used. Eq. (5B) yields $Q_{c}$ in cfh when $D$ and $H$ are in inches and $N$ is in $\mathrm{Hz}$ (see example in Fig. 3).

A typical design procedure begins with the selection of $\mathrm{C}_{\mathrm{H}}$ from an interval of 0.3 to 0.9 . The lower numbers, despite less then ideal use of power, tend to simplify the design on a small scale dominated by low submergence and high speed motors. The power efficiency, however, does become important for larger, deeper units and $\mathrm{C}_{\mathrm{H}}=0.9$ corresponding to the maximum $Q_{\mathrm{c}} H / P=$ $4.5 \frac{\mathrm{ft}^{4}}{\mathrm{Wh}}$ should be used to obtain the most economical solution.

When the aerator gas circulation rate $Q_{c}$ and the submergence $H$ are specified, the required power input $P$ at $\mathrm{C}_{\mathrm{H}}=0.9$ follows directly from $Q_{\mathrm{c}} H / P=4.5 \frac{\mathrm{ft}^{4}}{\mathrm{Wh}}$ (for $\mathrm{C}_{\mathrm{H}}$ other then 0.9 a plot of $Q_{\mathrm{c}} H / P$ vs. $\mathrm{C}_{\mathrm{H}}$ [4] can be used). The aerator rotor diameter is determined by solving (1B) for D

$$
\mathrm{D}=\sqrt[4]{\frac{Q_{\mathrm{c}}^{2} \mathrm{Eu}}{g H}},
$$

with the value for Eu given by (3B) or taken from Fig. 2. Finally, the aerator rotational speed is determined by solving (2B) for $N$ using the above value for $D$ :

$$
N=\sqrt{\frac{g H}{D^{2} \mathrm{C}_{\mathrm{H}}}}
$$

For $\mathrm{C}_{\mathrm{H}} \leq 0.9, P$ can be also calculated from

$$
P=1.09 \times 10^{-5} N^{3} D^{5}, \mathrm{~W}
$$

where $D$ is in inches and $N$ is in $\mathrm{Hz}$.

When, instead of the circulation rate $Q_{\mathrm{c}}$, the off-gas throughput rate $Q_{\mathrm{T}}$ and the conversion efficiency $E$ are specified, as in the case of gas-liquid absorption accompanied by chemical reaction, the aeration index $I=N D F_{\mathrm{c}}$ necessary to achieve that efficiency would have to be located on the plot of Fig. 1 in addition to selecting $\mathrm{C}_{\mathrm{H}}$, as the first step. From the performance and the economics points of view respectively, both parameters have profound effect on the 
aerator design and will, therefore, feature prominently throughout the scale-up procedure. Using the definitions of the circulation factor and the aeration index

$$
F_{\mathrm{c}}=\frac{Q_{\mathrm{c}}}{Q_{\mathrm{T}}}=\frac{I}{N D},
$$

the required circulation rate can be expressed in terms of the off-gas throughput and the aeration index:

$$
Q_{\mathrm{c}}=Q_{\mathrm{T}} \frac{I}{N D}
$$

Substitution of (2B) solved for $(N D)^{2}$ into (10B) squared, expresses it in terms of $\mathrm{C}_{\mathrm{H}}$

$$
Q_{\mathrm{c}}^{2}=Q_{\mathrm{T}}^{2} \frac{l^{2} \mathrm{C}_{\mathrm{H}}}{g H}
$$

Substitution of (11B) into (6B) leads to the aerator rotor diameter expressed in terms of the design parameters of interest:

$$
D=\sqrt[4]{\frac{l^{2} Q_{\mathrm{T}}^{2} \mathrm{EuC}_{\mathrm{H}}}{(g H)^{2}}}=\sqrt{\frac{I Q_{\mathrm{T}}}{g H}\left(\mathrm{EuC}_{\mathrm{H}}\right)^{1 / 4}}
$$

The aerator rotational speed $N$ is given by (7B) for the above value of $D$. Using (9B), the circulation factor $F_{\mathrm{c}}$ corresponding to these $N$ and $D$ and the circulation rate $Q_{\mathrm{c}}$ can be calculated.

In the described procedure the aerator submergence $H$ was treated as an independent parameter providing a degree of flexibility for selecting the aerator and the tank.

If proportionality between the aerator and the contactor geometry is to be preserved on scale-up, dimensionless submergence expressed in terms of the aerator rotor diameter can be used

$$
h=H / D
$$

Substitution of $H=h D$ into (12B) and (7B) yields expressions for $D$ and $N$ in terms of $h$ :

$$
D=\sqrt[3]{\frac{I Q_{\mathrm{T}}}{g h}\left(\mathrm{EuC}_{\mathrm{H}}\right)^{1 / 6}}
$$

and

$$
N=\sqrt{\frac{g h}{D C_{H}}}
$$

Any consistent units can be used in Eqs. (6B-15B). Note that $I$ has a dimension "length/time" and is shown in "in/s" in Fig. 1.

\section{Appendix C. Program for designing gas-liquid contactors with self- inducting turbo aerators

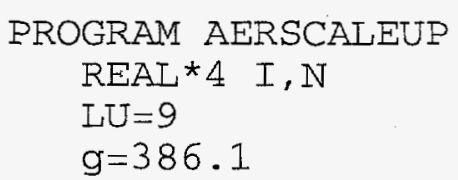




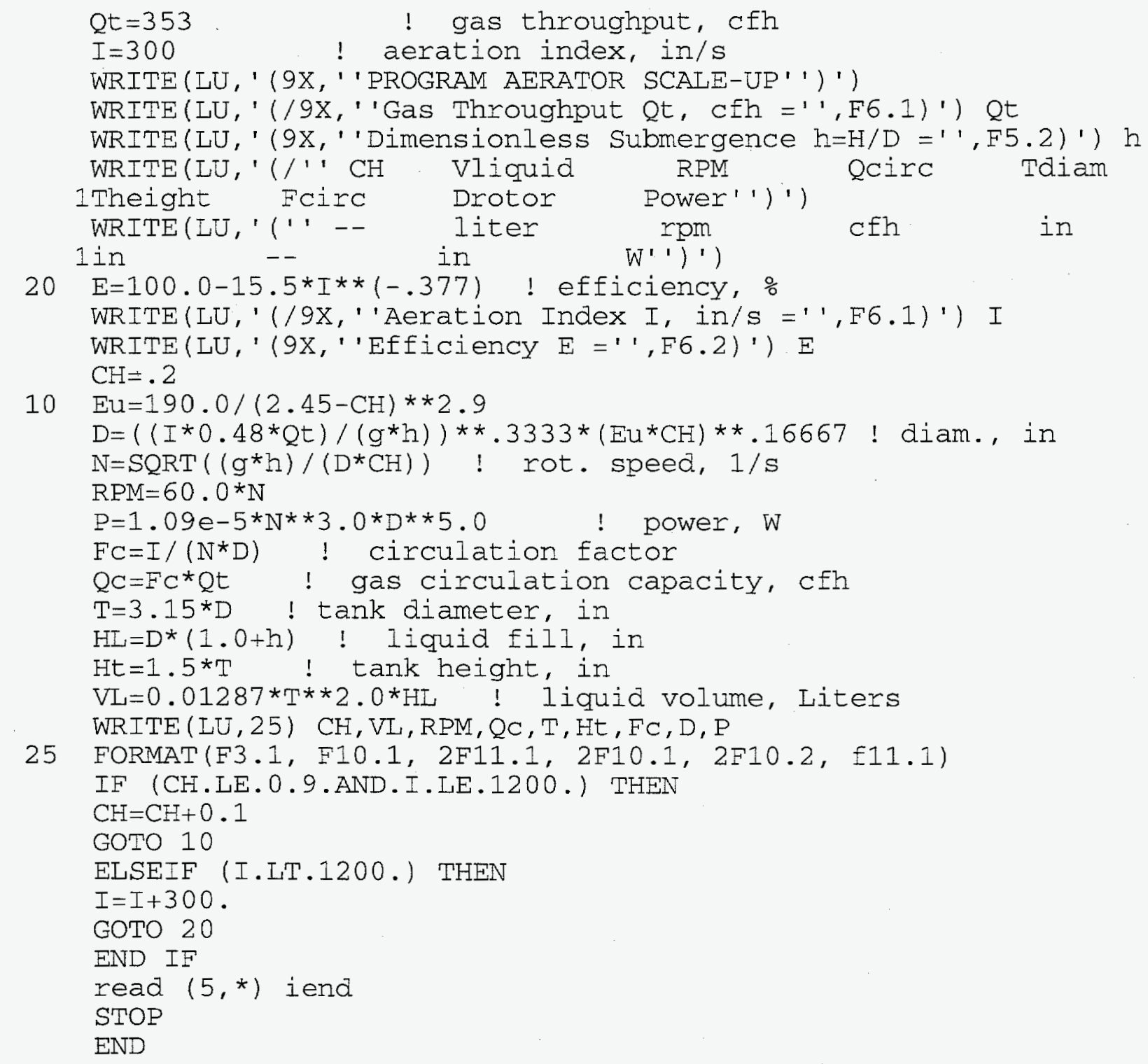

\section{Nomenclature}

$a=$ specific interfacial (the bubbles' surface per volume of liquid) area, $\mathrm{m}^{-1}$

$\mathrm{A}=22.4 \mathrm{~L} /$ mole $=$ Avogadro number

$C^{*}=$ gas solubility in water or aqueous solutions, $\mathrm{g} / \mathrm{m}^{3}$

$\mathrm{C}_{\mathrm{H}}=\frac{g H}{(N D)^{2}}=$ head coefficient

$D=$ aerator rotor diameter, $\mathrm{m}$

$D_{\mathrm{L}}=$ gas diffusivity in liquid phase, $\mathrm{m}^{2} / \mathrm{s}$

$E=$ conversion efficiency

$\mathrm{Eu}=\frac{g H}{\left(Q_{c / D^{2}}\right)^{2}}=$ Euler number

$F_{c}=Q_{\mathrm{C}^{\prime}} Q_{\mathrm{T}}=$ circulation factor 
$\mathrm{F}=96500$ coulomb $/$ mole $=$ Faraday number

$g=$ acceleration of gravity, $\mathrm{m} / \mathrm{s}^{2}$

$H=$ aerator submergence, $\mathrm{m}$

$H_{\mathrm{T}}=$ tank height, $\mathrm{m}$

$I=N D F_{c}$, the aeration index, $\mathrm{m} / \mathrm{s}$

$\mathrm{I}=$ current, $\mathrm{A}$

$k_{\mathrm{L}}=$ liquid film mass transfer coefficient, $\mathrm{m} / \mathrm{s}$

$N=$ rotor rotational speed, $\mathrm{rpm}, \mathrm{s}^{-1}$

$\left[\mathrm{NO}_{\mathrm{X}}{ }^{\text {out }}\right]=$ unconverted $\mathrm{NO}_{\mathrm{X}}$ concentration in off-gas, \%, ppm

$P=$ power consumption, $\mathrm{W}$

$Q_{\mathrm{C}}=$ gas circulation rate, $\mathrm{m}^{3} / \mathrm{s}$

$Q_{\mathrm{T}}=$ gas throughput, $\mathrm{m}^{3} / \mathrm{s}$

$Q_{\text {NOx }}{ }^{\max }=(\mathrm{I} \cdot \mathrm{A}) / 2 \mathrm{~F}=$ maximum possible $\mathrm{NO}_{\mathrm{x}}$ flow rate generated at the cathode, $\mathrm{m}^{3} / \mathrm{s}$

$Q_{\mathrm{NOx}}{ }^{\text {out }}=$ rate of unconverted $\mathrm{NO}_{\mathrm{x}}$ release, $\mathrm{m}^{3 / \mathrm{s}}$

$Q_{\mathrm{O} 2}{ }^{\text {sto }}=$ stoichiometric oxygen requirement for complete oxidation of nitrous acid, $\mathrm{m}^{3} / \mathrm{s}$

$Q_{\mathrm{O} 2}{ }^{\text {in }}=$ oxygen feed rate, $\mathrm{m}^{3} / \mathrm{s}$

$Q_{\mathrm{O} 2}{ }^{\text {con }}=$ oxygen consumption rate, $\mathrm{m}^{3 / \mathrm{s}}$

$r=$ mass transfer rate, $\mathrm{kg} / \mathrm{m}^{3} \mathrm{~s}$

$T=$ tank diameter, $\mathrm{m}$

$V_{\text {liq }}=$ liquid volume in $2 / 3$ filled tank, $\mathrm{m}^{3}$

\section{References}

(1) K. R. Jethani, N. J. Suchak and J. B. Joshi, Selection of Reactive Solvent For Pollution Abatement of $\mathrm{NO}_{\mathrm{X}}$, Gas Sep. Purif., 4, 9, (1990)

(2) A. Warshaw, Removal of Nitrogen Oxides From a Gas Stream - US Patent 3565575 (1971)

(3) Y. Zundelevich and E. Vigdorchik, Applications of Self-Inducting Impellers in Autoclave Leaching, Proc. All-Union Conf. on Application of Autoclave Technology in NonFerrous Metallurgy, Moscow, (1975)

(4) Y. Zundelevich, Power Consumption and Gas Capacity of Self-Inducting TurboAerators, AIChE Journal, 25, 763-773, (1979)

(5) P. H. Calderbank, Physical Rate Processes in Industrial Fermentation, Part II: The MassTransfer Coefficients for Gas-Liquid Contacting in Agitated Vessels, Trans. Inst. Chem. Engrs., (London) 37, 173 (1959)

(6) Perry's Chemical Engineers' Handbook, 6th ed., p. 3-103, McGraw-Hill, New York, 1984

(7) CRC Handbook of Chemistry and Physics, p. B-103, The Chemical Rubber Co., 1974 
(8) G. A. Hughmark, Power Requirements and Interfacial Area in Gas-Liquid Turbine Agitated Systems, Ind. Eng. Chem. Process Des. Dev., 19, 638-641, (1980) 